\title{
The relationship of the anterior inferior cerebellar artery diameter and the vascular loop type with the clinical manifestations in vascular loop syndrome: a clinical radiologic study
}

\author{
Vasküler loop sendromunda anterior inferior serebellar arterin çapı ve vasküler loop \\ tipinin klinik bulgular ile ilişkisi: klinik radyoloji çalışması
}

\author{
๑DFatih Çankal \\ Ankara Medipol University, School of Medicine, Department of Anatomy, Ankara, Turkey \\ Visart Imaging Center, Department of Radiology, Ankara, Turkey
}

Cite this article as/Bu makaleye atıf için: Çankal F. The relationship of the anterior inferior cerebellar artery diameter and the vascular loop type with the clinical manifestations in vascular loop syndrome: a clinical radiologic study. J Med Palliat Care 2021; 2(4): 124-130.

\begin{abstract}
Objective: Tinnitus and vertigo are common audiovestibular symptoms in the population. Many diseases can lead to the appearance of these symptoms, but the exact cause can often not be determined. It has been suggested that compression of the cranial nerves by vascular structures may be the cause of various clinical manifestations. This is known as microvascular compression syndrome. Some studies have stated that vascular compression syndromes are a serious pathology, while many studies have argued that vascular compression is only a radiological finding. We aimed to contribute to the literature on vascular compression syndrome and vascular loop types, which is still a controversial topic and to determine the location of the diameter change in the anterior inferior cerebellar artery in the compression syndrome.

Material and Method: Patients who underwent a Magnetic Resonance Imaging (MRI) examination of Temporal Bone due to a complaint of tinnitus or vertigo were retrospectively examined. The complaints of the patients, the diameters of the anterior inferior cerebellar artery (AICA) and the types of vascular loop were evaluated in the high resolution 3D fas imaging employing steady-state acquisition (FIESTA) sequence, according to the CHAVDA classification. The statistical relationship between the age of the patients, anterior inferior cerebellar artery diameters and vascular loop types and their clinical manifestations was investigated.

Results: A total of 52 patients were enrolled in the study, of which 28 (53.8\%) were male and 24 (46.2\%) were female. The mean age of all patients was $47.58 \pm 18.734$ years. The mean right AICA diameters of the patients were $1.10 \pm 0.206 \mathrm{~mm}$, the mean left AICA diameter was $1.11 \pm 0.253 \mathrm{~mm}$. Type 1 in 29 patients, type 2 in 12 patients, type 3 vascular loop in 4 patients were observed for the right side, while type 1 in 29 patient, type 2 in 12 patients, and type 3 in 7 patients were observed for the left side. There was no significant difference between vascular loop and tinnitus on the right and left ( $p=0.705 ; \mathrm{p}=0.335$, respectively). There was no significant difference between the right vascular loop and the left vascular loop and the vertigo ( $p>0.999 ; p=0.425$, respectively). There was no significant difference between the right tinnitus, left tinnitus and vertigo in terms of the diameters of the right and left AICA in the patients ( $\mathrm{p}=0.782 ; \mathrm{p}=0.762 ; \mathrm{p}=0.408 ; \mathrm{p}=0.915$, respectively).

Conclusion: Vascular compression syndromes are clinical conditions that show symptoms over cranial nerves. Although the vascular loop syndromes originating from AICA have been discussed a lot recently, it is seen that there is no definite opinion. In our study, no association of AICA diameter and vascular loop type with clinical findings was found.
\end{abstract}

Keywords: Vascular loop, anterior inferior cerebellar artery, vertigo, tinnitus

ÖZ

Amaç: Tinnitus ve vertigo popülasyonda yaygın görülen audiovestibuler semptomlardandır. Pek çok hastalık bu belirtilerin ortaya çıkmasına yol açabilir. Ancak kesin sebep çoğu zaman belirlenemez. Kranial sinirlerin vasküler yapılar tarafından kompresyonunun çeşitli klinik bulguların sebebi olabileceği öne sürülmüştür. Bu mikrovasküler kompresyon sendromu olarak bilinir. Bazı çalıșmalar vasküler kompresyon sendromlarının ciddi bir patoloji olduğunu ifade ederken pek çok çalıșmada ise vasküler kompresyonun sadece radyolojik bir bulgu olduğu savunulmaktadır. Halen tartışmalı bir konu olan vasküler kompresyon sendromu ve vasküler loop tipleri hakkında literatüre katkı sağlamayı, anterior inferior serebellar arterdeki (AICA) çap değişikliğinin kompresyon sendromundaki yerini belirlemeyi amaçladık.

Gereç ve Yöntem: Tinnitus veya vertigo şikayeti nedeniyle Temporal Kemik Manyetik Rezonans Görüntüleme tetkiki yapılan hastalar retrospektif olarak incelendi. Hastaların sikayetleri, anterior inferior serebellar arter'in çapı ve vasküler loop tipi CHAVDA sınıflandırmasına göre yüksek rezolüsyonlu 3 boyutlu fast imaging employing steady-state acquisition (FIESTA) sekansında değerlendirildi. Hastaların yaşı, anterior inferior serebellar arter çapları ve vasküler loop tipleri ile klinik bulguları arasındaki istatistiksel ilişki araştırıld.

Bulgular: Çalışmaya toplamda 52 hasta alınmış olup bu hastaların 28’i $(\% 53,8)$ erkek, 24’ü $(\% 46,2)$ kadındır. Tüm hastaların yaş ortalaması 47,58 $\pm 18,734$ yıldır. Hastaların sağ AICA

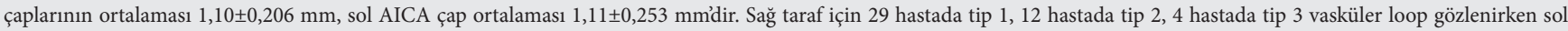
taraf için ise 29 hastada tip 1, 12 hastada tip 2, 7 hastada tip 3 gözlenmiștir. Sağda ve solda vasküler loop ile tinnitus arasında anlamlı bir farklılık bulunmamıștır (sırasıyla p=0,705; $\mathrm{p}=0$,335). Sağ vasküler loop ve sol vasküler loop ile vertigo arasında anlamlı bir farklılık bulunmamıștır (sırasıyla $p>0,999 ; \mathrm{p}=0,425$ ). Hastalarda sağ tinnitus, sol tinnitus ve vertigo görülüp görülmemesi arasında sağ ve sol AICA çapları açısından anlamı farklılık bulunmamıştır (sırasıyla $\mathrm{p}=0,782 ; \mathrm{p}=0,762 ; \mathrm{p}=0,408 ; \mathrm{p}=0,915$ ).

Sonuç: Vasküler kompresyon sendromları kranial sinirler üzerinden belirti gösteren klinik durumlardır. AICA kaynaklı vasküler loop sendromları son zamanlarda oldukça tartışılsa da kesin bir kanaat elde edilmediği görülmektedir. Çalışmamızda AICA çapının ve vasküler loop tipinin klinik bulgularla birlikteliği saptanmamıştır.

Anahtar Kelimeler: Vasküler loop, anterior inferior serebellar arter, vertigo, tinnitus 


\section{INTRODUCTION}

Tinnitus is the perception of a sound by the patient without any acoustic stimulus. It is a common disorder that occurs in $7-12 \%$ of the general population (1). It is known as a problem that mostly affects men between the ages of 40-70 (2). It can be pulsatile or non-pulsatile. If it is longer than 6 months, it is called chronic, if it is short, it is called acute (3-5). In the etiology of tinnitus, factors such as trauma, drugs, the common cold, and Menierés disease may take place. History taking, otolaryngological examination, neurological examination, and radiological methods help us to identify treatable causes of tinnitus (1). However, precise information about the etiology cannot be obtained in most patients $(1,3)$

Like tinnitus, sensorineural hearing loss (SNHL) and vertigo are common audiovestibular symptoms. Many diseases can cause these symptoms to occur. However, the exact cause cannot be determined most of the time (6).

It has been suggested that compression of the cranial nerves by vascular structures may be the cause of various clinical findings (7). This condition is known as microvascular compression syndrome $(1,8-10)$. Vascular compression can cause recurrent vertigo, fluctuating hearing loss, and tinnitus. Ocular motor dysfunction may accompany the picture (11).

In 1875 , hemifacial spasm due to facial nerve compression of a vertebral artery aneurysm is the first case reported as a sign of vascular compression (12). Trigeminal neuralgia has also been reported as neurovascular compression syndrome $(13,14)$. In 1936, McKenzie also reported that vascular compression may be associated with Menierés disease. (15). A case of vascular compression to the $5^{\text {th }}$ nerve without aneurysm was reported in 1959 (16). Ehni and Woltman also stated that vascular compression can cause hemifacial spasm (17). In 1975, Janetta showed that redundant arterial loops can cause clinical symptoms such as hearing loss, tinnitus, vertigo, and hemifacial spasm with microvascular compression $(14,18)$. Schwaber also suggested that vertigo, tinnitus, and sensorineural hearing loss occur due to hypofunction or hyperfunction of the 8th nerve (19). Reissner and Schuknecht claimed that there is no correlation with hearing loss, tinnitus, vertigo and Menieré (20).

It has been claimed that tinnitus, vertigo or hearing loss in vascular compression syndrome occurs by the mechanism of local demyelination, decrease in vascular perfusion, nerve reorganization or axonal hyperactivity in the nerve due to compression or a contact vessel (18,21-24) In some studies, the relationship between hearing loss and AICA in the internal acoustic canal (IAC) is mentioned, and in some studies, the relationship between AICA location and audiovestibular symptoms $(25,26)$.
AICA aneurysms can cause symptoms related to compression of the $5^{\text {th }}, 6^{\text {th }}, 7^{\text {th }}, 8^{\text {th }}, 9^{\text {th }}, 10^{\text {th }}$, and $11^{\text {th }}$ cranial nerves (27). Symptoms of aneurysmal compression, vascular loop syndromes and $8^{\text {th }}$ nerve tumor are the same (28). In this case, temporal bone MRI examination is a necessary condition.

MRI has become the standard for examination of the posterior fossa and IAC (29). Advances in MRI sequences have enabled detailed visualization of vascular structures and cranial nerves (7). MRI provides very useful information in patients with audiovestibular dysfunction (6).

We planned this study to contribute to the literature on vascular compression syndrome, which is still a controversial issue, and to contribute to the clinical manifestation of the diameter change in AICA, which may cause a mass effect similar to the aneurysm.

\section{MATERIAL AND METHOD}

This study was planned as a retrospective study. At all stages, the 1964 Declaration of Helsinki, national research committee standards and ethical guidelines were meticulously complied with. This study was approved by Ankara Medipol University Noninterventional Clinical Research Ethics Committee (Date: 23.09.2021, Decision No: 37).

\section{Study Plan and Patient Selection Criteria}

Patients who underwent temporal bone MRI examination at the imaging center between January 2020 and July 2021 were evaluated retrospectively. Patients who had undergone surgery, patients with infection, abscess, fracture, hematoma and malignant mass, and patients younger than 18 years of age were excluded from the study group. It was noted whether vertigo and/or tinnitus were present in the complaints of the remaining 52 patients. The type of vascular loop on 104 sides of 52 patients was determined, and the diameter of the anterior inferior cerebellar artery was measured (Figure 1-3).

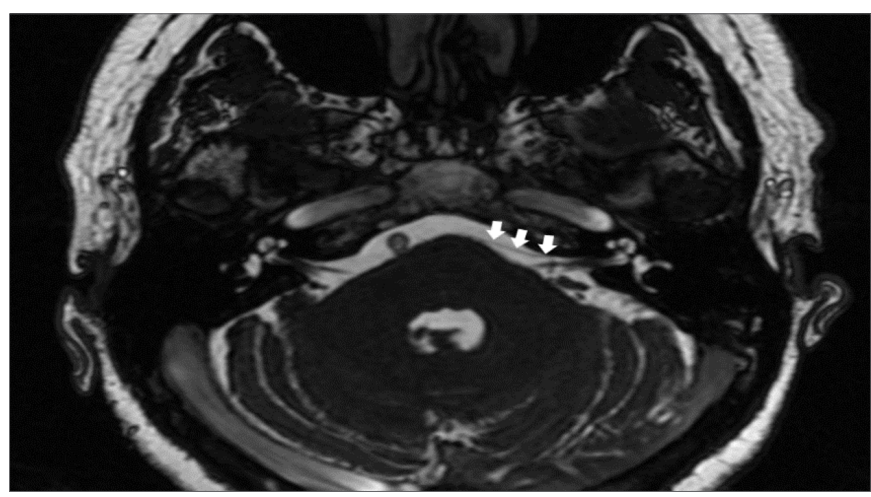

Figure 1. Type 1 vascular loop on the left (white arrows) 


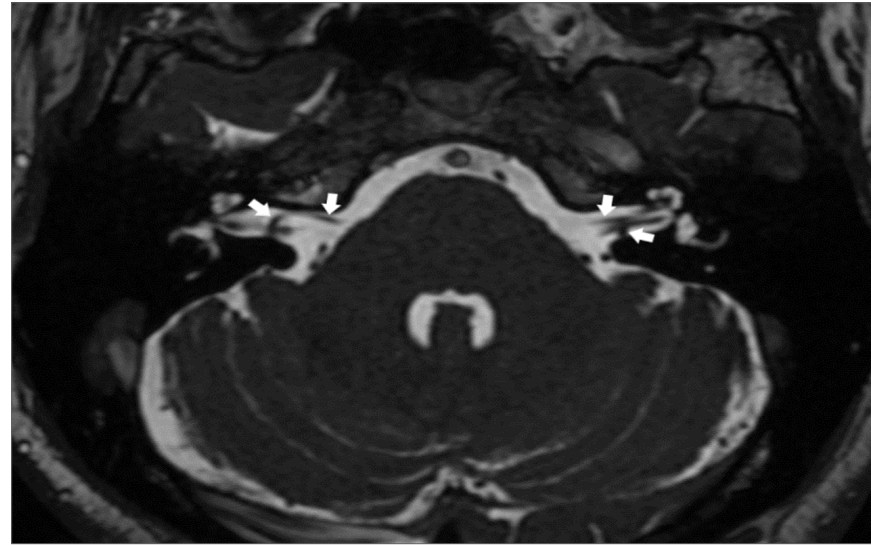

Figure 2. Bilateral type 2 vascular loop (white arrows)

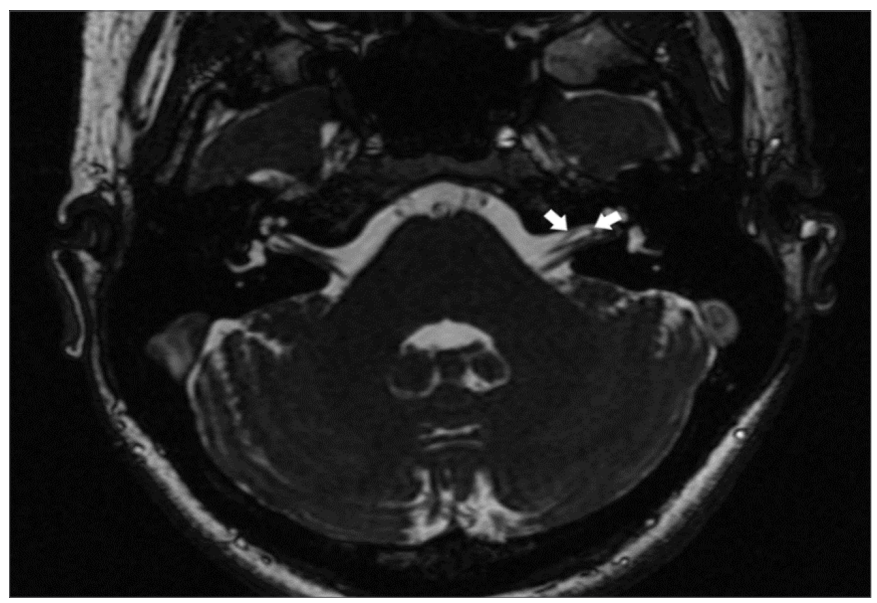

Figure 3. Type 3 vascular loop on the left (white arrows)

MRI examinations were performed using $1.5 \mathrm{~T}$ (Tesla) (Signa Explorer, GE Healthcare, USA) MRI scanners.

Routine sequences included in the standard protocol were taken in MRI examinations. Diameter of vascular structure and loop were evaluated axial and coronal high resolution 3D fast imaging employing steady-state acquisition (FIESTA) (TR: $6.5 \mathrm{~ms}$; TE: $2.5 \mathrm{~ms}$; section thickness: $1 \mathrm{~mm}$; slice spacing: $0.7 \mathrm{~mm}$; matrix: $416 \mathrm{x}$ 416; field of view: $200 \times 200 \mathrm{~mm}$ ) sequence.

Images in the collection environment of the center were examined on two separate dates by a radiologist with 22 years of experience using the Picture Archiving and Communication System (PACS).

\section{Statistical Analysis}

In the study, mean \pm standard deviation for numerical parameters, number (n) and percentage (\%) for categorical data were given as descriptive statistics. Student's t test was used for comparisons between groups for each side, since parametric test assumptions were met, and Fisher's exact test was used for comparison of categorical data. Pearson chi-square test was used to examine the linear relationship. $\mathrm{P}<0.05$ was considered statistically significant in the analyses. All analyzes were made using IBM SPSS v22 program.
Intra-observer reliability coefficients were determined using Pearson correlation coefficients. Reliability coefficients above 0.7 were considered acceptable.

\section{RESULTS}

A total of 52 patients were included in the study, of which $28(53.8 \%)$ were male and $24(46.2 \%)$ were female. The mean age of all patients was $47.58 \pm 18.734$ years. In the study, right AICA could not be visualized in 7 of 52 patients and left AICA in 4 patients. The mean right diameter of 45 patients was $1.10 \pm 0.206$ $\mathrm{mm}$, and the mean left diameter of 48 patients was $1.11 \pm 0.253 \mathrm{~mm}$. For the right side, type 1 vascular loop was observed in 29 patients, type 2 in 12 patients, and type 3 in 4 patients, while for the left side, type 1 was observed in 29 patients, type 2 in 12 patients, and type 3 in 7 patients.

The distribution of the number of patients according to vascular loop types is given in Table $\mathbf{1}$.

\begin{tabular}{|c|c|c|}
\hline \multirow{2}{*}{ GROUP } & \multicolumn{2}{|c|}{ Vascular Loop } \\
\hline & Right n (\%) & Left n (\%) \\
\hline Type 1 & $29(64.4)$ & $29(60.4)$ \\
\hline Type 2 & $12(26.7)$ & $12(25.0)$ \\
\hline Type 3 & $4(8.9)$ & $7(14.6)$ \\
\hline
\end{tabular}

There was no significant difference between the right vascular loop and tinnitus right, and between the left vascular loop and tinnitus left $(\mathrm{p}=0.705 ; \mathrm{p}=0.335$, respectively) (Table 2).

\begin{tabular}{|c|c|c|c|c|c|}
\hline $\begin{array}{l}\text { Vascular } \\
\text { Loop Right }\end{array}$ & $\begin{array}{c}\text { Tinnitus } \\
\text { Right } \\
\text { n (\%) }\end{array}$ & $\mathbf{p}^{*}$ & $\begin{array}{l}\text { Vascular } \\
\text { Loop Left }\end{array}$ & $\begin{array}{c}\text { Tinnitus } \\
\text { Left } \\
\text { n (\%) }\end{array}$ & $\mathbf{p}^{*}$ \\
\hline Type 1 & $9(31.0)$ & \multirow{3}{*}{0.705} & Type 1 & $6(20.7)$ & \multirow{3}{*}{0.335} \\
\hline Type 2 & $4(33.3)$ & & Type 2 & $5(41.7)$ & \\
\hline Type 3 & $2(50.0)$ & & Type 3 & $2(28.6)$ & \\
\hline
\end{tabular}

There was no significant difference between right vascular loop and left vascular loop with vertigo ( $>0.999, p=0.425$ respectively) (Table 3 ).

\begin{tabular}{|c|c|c|c|c|c|}
\hline $\begin{array}{l}\text { Vascular } \\
\text { Loop Right }\end{array}$ & $\begin{array}{c}\text { Vertigo } \\
\text { n (\%) }\end{array}$ & $\mathbf{p}^{*}$ & $\begin{array}{c}\text { Vascular } \\
\text { Loop Left }\end{array}$ & $\begin{array}{c}\text { Vertigo } \\
\text { n (\%) }\end{array}$ & $\mathbf{p}^{*}$ \\
\hline Type 1 & $11(37.9)$ & \multirow{3}{*}{$>0.999$} & Type 1 & $6(20.7)$ & \multirow{3}{*}{0.425} \\
\hline Type 2 & $5(41.7)$ & & Type 2 & $5(41.7)$ & \\
\hline Type 3 & $1(25.0)$ & & Type 3 & $2(28.6)$ & \\
\hline
\end{tabular}


There was no significant difference between the presence of right tinnitus, left tinnitus and vertigo in terms of diameter right/left $(\mathrm{p}=0.780 ; \mathrm{p}=0.762 ; \mathrm{p}=0.408 ; \mathrm{p}=0.915$, respectively) (Table 4-6).

\begin{tabular}{lccc|}
\hline \multicolumn{4}{l}{ Table 4. Comparison of diameter in terms of vertigo } \\
& Vertigo Negative & Vertigo Positive & $\mathbf{p}^{*}$ \\
\hline Diameter Right $(\mathrm{mm})$ & $1.08 \pm 0.200$ & $1.14 \pm 0.218$ & 0.408 \\
Diameter Left $(\mathrm{mm})$ & $1.11 \pm 0.258$ & $1.12 \pm 0.251$ & 0.915 \\
\hline *: Student's t Test & & & \\
\hline
\end{tabular}

\begin{tabular}{|lccc|}
\hline Table 5. Comparison of diameter in terms of right tinnitus & \\
\hline & $\begin{array}{c}\text { Tinnitus Right } \\
\text { Negative }\end{array}$ & $\begin{array}{c}\text { Tinnitus Right } \\
\text { Positive }\end{array}$ & $\mathbf{p}^{*}$ \\
\hline Diameter Right $(\mathrm{mm})$ & $1.10 \pm 0.223$ & $1.11 \pm 0.164$ & 0.780 \\
\hline *: Student's $\mathrm{t}$ Test & & & \\
\hline
\end{tabular}

Table 6. Comparison of diameter in terms of left tinnitus

\begin{tabular}{|lccc|} 
& $\begin{array}{c}\text { Tinnitus Left } \\
\text { Negative }\end{array}$ & $\begin{array}{c}\text { Tinnitus Left } \\
\text { Negative }\end{array}$ & $\mathbf{p}^{*}$ \\
\hline Diameter Left $(\mathrm{mm})$ & $1.11 \pm 0.274$ & $1.13 \pm 0.193$ & 0.762 \\
\hline *: Student's t Test & & & \\
\hline
\end{tabular}

There was no linear relationship between age and right diameter and between age and left diameter $(p=0.386$; $p=0.100$, respectively). There was no significant age difference between right and left vascular loop types $(\mathrm{p}=0.864 ; \mathrm{p}=0.075$, respectively).

There was no significant difference in age between the presence of right tinnitus, left tinnitus and vertigo in the patients $(\mathrm{p}=0.252 ; \mathrm{p}=0.329 ; \mathrm{p}=0.785$, respectively).

The reliability of the measurements was tested, the intraobserver reliability were found between $0.95-0.98$. Results were considered safe and measurements were averaged.

\section{DISCUSSION}

AICA originates from the basilar artery and is usually in the form of a single root, surrounds the pons near the $6^{\text {th }}, 7^{\text {th }}$ and $8^{\text {th }}$ nerves (30). Fomkina et al. (31) described AICA as the smallest all of cerebellar arteries. Its course varies widely among individuals (27). AICA branches off from the basilar artery and provides blood supply to the labyrinth, brainstem, and cerebellum. The course shows variation. In some cases it can be seen in the IAC (20). The labyrinthine artery, a branch of AICA, is the only artery of the labrynth, cochlea and vestibular organs (32).

Cerebellar infarction at the AICA irrigation territory causes unilateral hearing loss (33). AICA occlusion is a serious problem for the patient, especially if the posterior inferior cerebellar artery (PICA) is thin (34). It has even been said that occlusion of AICA can be fatal. It may cause ischemic necrosis of the membranous labyrinth, spinal tract, trigeminal nerve, or mid-lower cerebellar peduncle (20).

Kim et al. (35) stated that ischemia in the labyrinthine artery, which is a branch of AICA, may cause idiopathic sudden sensorineural hearing loss (ISSHL), while variations of AICA are not effective on ISSHL, vertigo and tinnitus. However, in the same study, it was reported that the shape of AICA in cerebellopontine angle may make a difference in the quantitative evaluation of hearing.

Sunderland (36) reported that AICA was intimately related to the facial and vestibulocochlear nerves in $64 \%$ of cases.

AICA aneurysms may show signs of mass effect or subarachnoid hemorrhage (27). This information was the reason why we included the diameter measurement while planning this study. However, we could not prove the relationship between diameter changes and audiovestibular symptoms.

McDermott et al. (7) introduced a new classification of the AICA vascular loop in 2003 (Chavda classification). Accordingly, if they saw AICA in cerebellopontine angle (CPA), they called it type I vascular loop. It enters the IAC, but if it is more than $50 \%$, they classify it as type II, if it is more than $50 \%$ extended in IAC, they classify it as type III vascular loop. In previous cadaver studies, AICA was determined as $19-40 \%$ outside the pore, $33-56 \%$ in the pore, and $25-27 \%$ within the IAC. In our study, $64.4 \%$ type I, $26.7 \%$ type II and $8.9 \%$ type III on the right; $60.4 \%$ type I, 25\% type II and 7\% type III on the left, vascular loop appearance is consistent with the literature findings.

In their study using the Chavda classification, Erdoğan et al. (29) examined 374 temporal bones of 187 patients and stated that 108 of them had vascular loops. However, there seems to be some confusion in the literature for the definition of the vascular loop. Because in most cases, all AICAs are evaluated in three types according to their localization, regardless of whether a figural loop is seen or not. McDermott (7) classified all AICAs as vascular loops. In our opinion, Erdoğan et al's approach is more accurate in terms of the vascular loop. Since in our study we measured the diameter of all AICAs, not just the loop, we preferred the Chavda classification to describe the localization. However, our recommendation is to modify the Chavda classification and name the types as AICA types, not as AICA vascular loop types.

Another classification for the AICA vascular loop is the Gorrie classification. Accordingly, type 1: no contact, type 2 : adjacent, type 3 : displacement in $8^{\text {th }}$ nerve, type 4 : displacement in $7^{\text {th }}$ and $8^{\text {th }}$ nerves $(26)$.

Prior to the Chavda classification, which was first reported in McDermott et al. (7) AICA localization was determined by its occurrence in $\mathrm{CPA}$, in the pore 
(internal acoustic pore), and IAC. Prior to this study, AICA localization was reported between 19-78\% in CPA, $12-56 \%$ in the pore, and $5-27 \%$ in the canal in radiological and cadaveric studies (36-38).

McDermott et al. (7) succeeded in imaging $100 \%$ of AICA in $3 \mathrm{D}$ CISS sequence in their MR-based radiological study. In their radiological study, Akgün et al. (39) reported that AICA was not observed on the right in $17.8 \%$ of cases and on the left in $18.5 \%$ of cases. On the other hand, Fomkina et al. (31) reported the absence of AICA bilaterally in 16\% and unilaterally in 33\% in their cadaveric study. In our study, we could not follow AICA bilaterally in some examinations. Our AICA incidence rates are $86.5 \%(45 / 52)$ on the right and $92.3 \%(48 / 52)$ on the left, which can be considered as high data among the incidence rates presented in a large series. We think that the high rates in recent studies are due to innovations in $\mathrm{MR}$ technology and require the use of custom sequences to be encouraged.

Akgün et al. (39) measured AICA diameter as $1.26 \pm 0.43$ $\mathrm{mm}$ in one of the rare radiological studies measuring AICA diameter, and they did not mention clinical data in the study. In cadaveric studies, the AICA diameter was reported as $1.34 \pm 0.28 \mathrm{~mm}$ by Kawashima et al. (33) and $1.09 \pm 0.06 \mathrm{~mm}$ by Fomkina et al. (31). In our study, diameter averages are also compatible with these data. It is said that the different findings in cadaver studies may be due to fixation (40).

Nowé et al. (1) found in their study that 10 of 12 patients with vascular tinnitus and 41 of 46 patients with nonpulsatile tinnitus had a vascular loop in the internal acoustic canal. De Ridder et al. (10) said that there is a strong relationship between pulsatile tinnitus and the vascular loop. Demir et al. (3) in their recent study, found that the type II vascular loop increased significantly in tinnitus clinic by creating vascular compression. In our study, however, no relationship was found between vascular loop types and vertigo or tinnitus.

McDermott et al. (7) said that there is no relationship between tinnitus and the vascular loop, but they say there is a relationship between hearing loss and type II and type III vascular loops. McDermott et al. found no correlation between vascular loop calibration and clinical data. This is the only study investigating the relationship between the calibration of the AICA vascular loop and audiovestibular symptoms. However, in this study, the diameter of the vascular loop was not measured, and it was evaluated as 'large' or 'small' according to the facial nerve. Present study is the first in the literature to investigate the relationship between AICA diameter and tinnitus and vertigo. Although we could not detect a relationship between clinical findings and diameter in our study, we think that it is possible that studies in larger series will yield different results.

Gültekin et al. (41) also found no relationship between tinnitus and vascular loop types. In the same study, the angulation of the $8^{\text {th }}$ nerve caused by the vascular structure was also examined, and they reported that the contribution of vascular compression syndromes to audiovestibular symptoms such as vertigo and tinnitus is not clear, and therefore operations to be performed may be unnecessary. Ryu et al. $(8,9)$ on the other hand, recommended early decompression to prevent irreversible damage to the nerve.

Sirikci et al. (42) reported that there was no relationship between the vascular loop and nonspecific cochleovestibular symptoms.

Grocoske et al. (43) in their study investigating tinnitus and hypoacusis, could not find a relationship with the vascular loop and stated that the vascular loop is not a pathology but an MRI finding.

Erdoğan et al. (29) also reported that the presence, localization, or nerve contact is not related to clinical symptoms.

We do not have clear information about the etiology of the vascular loop. Senile elongation has been suggested (28). However, in our study, no relationship was found between age and diameter or tinnitus types.

\section{CONCLUSION}

Vascular compression syndromes are clinical conditions that manifest through cranial nerves. Studies on the clinical implications of vascular loop types originating from AICA have yielded different results. In our study, no association of AICA diameter and vascular loop type with clinical findings was found. Our recommendation is to study in large series with all the features of the vascular structures. Thus, protecting patients from unnecessary surgical interventions; however, for patients who need it, strong evidence can be obtained that will enable an operation decision to be made without delay.

\section{ETHICAL DECLARATIONS}

Ethics Committee Approval: This study was approved by Ankara Medipol University Non-interventional Clinical Research Ethics Committee (Date: 23.09.2021, Decision No: 37$)$.

Informed Consent: Because the study was designed retrospectively, no written informed consent form was obtained from patients.

Referee Evaluation Process: Externally peer-reviewed.

Conflict of Interest Statement: The author has no conflicts of interest to declare. 
Financial Disclosure: The author declared that this study has received no financial support.

Author Contributions: The author declares that they have all participated in the design, execution, and analysis of the paper, and that they have approved the final version.

Acknowledgments: We would like to express our gratitude to Dr. Tuğçe Şirinoğlu and Dr. Dilara Patat for their valuable contributions in conducting the research in an orderly manner, statistical analysis and editing the results.

\section{REFERENCES}

1. Nowé V, De Ridder D, Van de Heyning PH, et al. Does the location of a vascular loop in the cerebellopontine angle explain pulsatile and non-pulsatile tinnitus? Eur Radiol 2004; 14: 2282-9.

2. Aksoy S, Firat Y, Alpar R. The tinnitus handicap inventory: A study of validity and reliability. Int Tinnitus J 2007; 13: 94-8.

3. Demir E, Beyazal Celiker F, Celiker M, Aydin Balaban G, Dursun E. The effect of vascular loop in the tinnitus severity. Akd Med J 2020; 2: 249-55

4. Wu D, Zheng Y, Chen Z, Ma Y, Lu T. Further validation of the Chinese (Mandarin) Tinnitus Handicap Inventory: comparison between patient-reported and clinicalinterviewed outcomes. Int J Audiol 2018; 57: 440-8.

5. Formánek M, Migal’ová $\mathrm{P}, \mathrm{Krulová} \mathrm{P}$, et al. Combined transcranial magnetic stimulation in the treatment of chronic tinnitus. Ann Clin Transl Neurol 2018; 5: 857-64.

6. Zidan, M.A., Almansor, N. Presence of vascular loop in patients with audio-vestibular symptoms: is it a significant finding? Evaluation with 3-tesla MRI 3D constructive interference steady state (CISS) sequence. Egypt J Radiol Nucl Med 2020; 51, 114.

7. McDermott AL, Dutt SN, Irving RM, Pahor AL, Chavda SV. Anterior inferior cerebellar artery syndrome: fact or fiction. Clin Otolaryngol Allied Sci 2003; 28: 75-80.

8. Ryu H, Yamamoto S, Sugiyama K, et al. Neurovascular compression syndrome of the eight cranial nerve: what are the most reliable diagnostic signs? Acta Neurochir (Wien) 1998; 140: 1279-86.

9. Ryu H, Yamamoto S, Sugiyama K, et al. Can the site of compression explain the symptoms? Acta Neurochir (Wien) 1999; 141: 495301.

10. De Ridder D, De Ridder L, Nowe' V, et al. Pulsatile tinnitus and the intrameatal vascular loop: why do we not hear our carotids? Neurosurgery 2005; 57: 1213-17.

11.Lee H. Neuro-otological aspects of cerebellar stroke syndrome. J Clin Neurol 2009; 5: 65-73.

12.Schultze, F. Linksseitiger facialiskrampf in folge eines aneurysma der arteria vertebralis sinistra. Archive Pathol Anat 1875; 65: 385-91.

13. Dandy WE. Concerning the cause of trigeminal neuralgia. Am J Surg 1934; 24: 447-55.

14. Jannetta PJ. Cranial nerve vascular compression syndromes (other than tic douloureux and hemifacial spasm). Clin Neurosurg 1981; 28: 445-56.

15. McKenzie KG. Intracranial division of the vestibular portion of the auditory nerve for Meniere's disease. Can Med Assoc J 1936; 34: 369-81.

16. Gardner WJ, Miklos MV. Response of trigeminal neuralgia to decompression of sensory root: discussion of cause of trigeminal neuralgia. JAMA 1959; 170: 1773-6.
17. Ehni G, Woltman HW. Hemifacial Spasm: Review of one hundred and siz cases. Arch Neur Psych 1945; 53: 205-11.

18. Janetta PJ. Neurovascular cross-compression in patients with hyperactive dysfunction of the eighth cranial nerve. Surg Forum 1975; 26: 467-9.

19.Schwaber MK, Hall W. Cochleovestibular nerve compression syndrome: clinical features and audiovestibular test findings. Laryngoscope 1992; 102: 1020-9.

20. Reisser C, Schuknecht HF. The anterior inferior cerebellar artery in the internal auditory canal. Laryngoscope 1991; 101: 761-6.

21. Markowski J, Gierek T, Kluczewska E, Witkowska M. Assessment of vestibulocochlear organ function in patients meeting radiologic criteria of vascular compression syndrome of vestibulocochlear nerve--diagnosis of disabling positional vertigo. Med Sci Monit 2011; 17: CR169-73.

22. Moller AR.Vascular compression of cranial nerves. II. Pathophysiology. Neurol Res 1999; 21: 439-43.

23. Makins AE, Nikolopoulos TP, Ludman C, O’Donoghue GM. Is there a correlation between vascular loops and unilateral auditory symptoms? Laryngoscope 1988; 108: 1739-42.

24.Brandt T, Dieterich M. VIII nerve vascular compression syndrome: vestibular paroxysmia. Baillieres Clin Neurol 1994; 3: 565-75.

25. Moosa S, Fezeu F, Kesser BW, Ramesh A, Sheehan JP. Sudden unilateral hearing loss and vascular loop in the internal auditory canal: case report and review of literature. J Radiosurg SBRT 2015; 3: 247-55.

26. Gorrie A, Warren 3rd FM, De la Garza AN, Shelton C, Wiggins 3rd RH. 2010. Is there a correlation between vascular loops in the cerebellopontine angle and unexplained unilateral hearing loss? Otology \& Neurotology 2010; 31: 48-52

27. Yamakawa H, Hattori T, Tanigawara T, Sahashi Y, Ohkuma A. Intracanalicular aneurysm at the meatal loop of the distal anterior inferior cerebellar artery: a case report and review of the literature. Surg Neurol 2004; 61: 82-8.

28. Applebaum EL, Valvassori GE. 1984. Auditory and vestibular system findings in patients with vascular loops in the internal auditory canal. Annals of Otology, Rhinology and Laryngology: Supplement 1984; 112: 63-70.

29. Erdogan N, Altay C, Akay E, et al. MRI assesment of internal acoustic canal variations using 3D-FIESTA sequences. Eur Arch Otorhinolaryngol 2013; 270: 469-75.

30. Kawashima M, Rhoton AL, Tanriover N, Ulm AJ, Yasuda A, Fujii K. Microsurgical anatomy of cerebral revascularization. Part II: Posterior circulation. Jf Neurosurg 2005; 102: 132-47.

31. Fomkina OA, Nikolenko VN, Chernyshkova EV. Morphology and biomechanical properties of cerebellar arteries in adults. RusOMJ 2016; 5: e0205.

32. Kim HN, Kim YH, Park IY, Kim GR, Chung IH. Variability of the surgical anatomy of the neurovascular complex of the cerebellopontine angle. Annals of Otology, Rhinology and Laryngology 1990; 99: 288-96 .

33. Lee H, Cho YW. Auditory disturbance as a prodrome of anterior inferior cerebellar artery infarction. J Neurol Neurosurg Psychiatry 2003; 74: 1644-8.

34. Atkinson WJ The anterior inferior cerebellar artery. J Neurol Neurosurg Psychiatry 1949; 12: 137-51.

35. Kim SH, Ju YR, Choi JE, Jung JY, Kim SY, Lee MY. Anatomical location of AICA loop in CPA as a prognos- tic factor for ISSNHL. PeerJ 2019; 7: e6582.

36. Sunderland $S$. The arterial relations of the internal auditorymeatus. Brain 1945; 68: 23-7.

37. Mazzoni A, Hansen CC. Surgical anatomy of the arteries of the internal auditory canal. Arch Otolaryngol Head Neck Surg 1970; 91: 128-35. 
38. Oaknine GE. The arterial loops of the pontocerebellar angle. Adu Otorhinolaryngol 1982; 28: 121-38.

39. Akgun V, Battal B, Bozkurt Y et al. Normal anatomical features and variations of the vertebrobasilar circulation and its branches: an analysis with 64-detector row CT and $3 \mathrm{~T}$ MR angiographies. Sci World J 2013; 29: 620162.

40. Fkuda H, Ishikawa, Okumura R. Demonstration of neurovascular compression in trigeminal neuralgia and hemifacial spasm with magnetic resonance imaging: comparison with surgical findings in 60 consecutive cases. Surg Neurol 2003; 59: 93-100.

41. Gultekin S, Celik H, Akpek S, Oner Y, Gumus T, Tokgoz N Am J Neuroradiol 2008; 29: 1746-9.

42.Sirikci A, Beyazit Y, Ozer E, et al. Magnetic resonance imaging based classification of anatomic relationship between the cochleovestibular nerve and anterior inferior cerebellar artery in patients with nonspecific neuro-otologic symptoms. Surg Radiol Anat 2005; 27: 531-5.

43. Grocoske FLB, Mendes RCCG, Vosguerau R, Mocellin M, de Oliveira MTCR, Koerner HN. Neurotology findings in patients with diagnosis of vascular loop of cranial nerves VIII in magnetic resonance imaging. Arq Int Otorrinolaringol 2011; 15: 418-25. 